\title{
Convergence and Divergence: Signal Perception and Transduction Mechanisms of Cold Stress in Arabidopsis and Rice
}

\author{
Xiaoshuang Wei ${ }^{1}$, Shuang Liu ${ }^{2}$, Cheng Sun ${ }^{2}$, Guosheng Xie ${ }^{2, *(D)}$ and Lingqiang Wang ${ }^{1, *}$ \\ 1 State Key Laboratory for Conservation and Utilization of Subtropical Agro-Bioresources, College of \\ Agriculture, Guangxi University, Nanning 530004, China; 1917301040@st.gxu.edu.cn \\ 2 MOA Key Laboratory of Crop Ecophysiology and Farming System in the Middle Reaches of the Yangtze \\ River, College of Plant Science and Technology, Huazhong Agricultural University, Wuhan 430070, China; \\ 2018301110013@webmail.hzau.edu.cn (S.L.); 13707255053@webmail.hzau.edu.cn (C.S.) \\ * Correspondence: xiegsh@mail.hzau.edu.cn (G.X.); lqwang@gxu.edu.cn (L.W.)
}

\section{check for} updates

Citation: Wei, X.; Liu, S.; Sun, C.; Xie, G.; Wang, L. Convergence and Divergence: Signal Perception and Transduction Mechanisms of Cold Stress in Arabidopsis and Rice. Plants 2021, 10, 1864. https://doi.org/ 10.3390/plants10091864

Academic Editors: Abidur Rahman,

\section{Balakrishnan Prithiviraj,}

Mohammad Aslam and M

Arif Ashraf

Received: 3 August 2021

Accepted: 6 September 2021

Published: 9 September 2021

Publisher's Note: MDPI stays neutral with regard to jurisdictional claims in published maps and institutional affiliations.

Copyright: (c) 2021 by the authors. Licensee MDPI, Basel, Switzerland. This article is an open access article distributed under the terms and conditions of the Creative Commons Attribution (CC BY) license (https:/ / creativecommons.org/licenses/by/ $4.0 /)$.

\begin{abstract}
Cold stress, including freezing stress and chilling stress, is one of the major environmental factors that limit the growth and productivity of plants. As a temperate dicot model plant species, Arabidopsis develops a capability to freezing tolerance through cold acclimation. The past decades have witnessed a deep understanding of mechanisms underlying cold stress signal perception, transduction, and freezing tolerance in Arabidopsis. In contrast, a monocot cereal model plant species derived from tropical and subtropical origins, rice, is very sensitive to chilling stress and has evolved a different mechanism for chilling stress signaling and response. In this review, the authors summarized the recent progress in our understanding of cold stress response mechanisms, highlighted the convergent and divergent mechanisms between Arabidopsis and rice plasma membrane cold stress perceptions, calcium signaling, phospholipid signaling, MAPK cascade signaling, ROS signaling, and ICE-CBF regulatory network, as well as light-regulated signal transduction system. Genetic engineering approaches of developing freezing tolerant Arabidopsis and chilling tolerant rice were also reviewed. Finally, the future perspective of cold stress signaling and tolerance in rice was proposed.
\end{abstract}

Keywords: cold stress; signal perception; signal transduction pathways; Arabidopsis; rice

\section{Introduction}

Cold stress limits the geographical distribution, growth habits, and productivity of plants [1]. There are two types of cold stress, including chilling stress $\left(0\right.$ to $\left.15^{\circ} \mathrm{C}\right)$ and freezing stress (below $0^{\circ} \mathrm{C}$ ). Many temperate plants, such as Arabidopsis, rapeseed, wheat, and rye, have acquired a complex network that senses and responds to freezing stress. Molecular mechanisms and regulation networks of plasma membrane cold perception, signaling and freezing stress tolerance of these plants have been well-reviewed [2-9]. On the other hand, rice (Oryza sativa L.), one of the most important cereal crops, is susceptible to chilling stress, especially in high elevation and high latitude temperate zones [10]. Many novel regulatory genes have been identified in chilling stress perception and signaling in rice in the past decade [11-13]. This allows us to compare and distinguish the similarities and differences of cold stress sensing and signaling mechanisms between Arabidopsis and rice $[8,9]$.

Plants respond to the decreased temperatures through sophisticated processes at different levels. Initially, plant cells perceive cold stress signals through the plasma membrane (PM) rigidification, PM-bound G-protein associated receptors, or cold sensors, such as $\mathrm{Ca}^{2+}$ influx channels, two-component histidine kinases, protein and nucleic acid conformations, or metabolite concentrations $[6,14]$. Then, the second messengers, including calcium ion, reactive oxygen species (ROS), and inositol phosphates, are generated. These second messengers further modulate the intracellular calcium $\left(\mathrm{Ca}^{2+}\right)$ level. Perturbation in cytosolic 
$\mathrm{Ca}^{2+}$ level is sensed by calcium-binding protein $\left(\mathrm{Ca}^{2+}\right.$ sensors), which interact with their target proteins, to transduce calcium signal in the cell. These proteins orchestrate cold stress signal transduction, activate protein phosphorylation cascades, and adjust the expression of transcription factors and cold regulated (COR) genes in plants [6].

This review summarized the recent progress in (i) cold stress perceptions, including PM-associated receptor-like kinases (RLK) and cold sensors; (ii) cold stress signaling mechanisms, including calcium signaling, phospholipids signaling, MAPK (mitogen-activated protein kinase) cascade signaling, and ROS signaling; (iii) ICE (inducer of CBF expression)CBF (C-repeat binding factor) transcriptional regulatory network; (iv) the light-regulated signal transduction system in cold stress tolerance. We highlighted the similarities and differences in cold-induced responses contributing to freezing tolerant Arabidopsis and chilling tolerant rice. Finally, we evaluated the genetic engineering for improving cold stress tolerance in plants and explored future research of cold stress signaling and tolerance mechanism in rice.

\section{Cold Stress Perceptions at Plasma Membrane (PM) in Arabidopsis and Rice}

One of the major consequences of the temperature downshift is a decrease in membrane fluidity affecting membrane-associated cellular functions, and the PM is proposed as a primary sensor of low-temperature stress [15-17]. The feature of primary perception of temperature in plants has been proposed [18]. Different microdomains with lipid raft formation and composition, including sphingolipids in the PM, are responsible for sensing the particular temperature ranges $[8,15]$. Many putative calcium channels, PM-bound G-protein associated receptors, plasma membrane-localized receptor-like kinases (RLKs) have been identified as cold sensors in plants. Calcium channels responsible for $\mathrm{Ca}^{2+}$ influx have been considered a major sensor class for low temperature [19-21]. Through the membrane rigidification-activated mechano-sensitive or ligand-activated $\mathrm{Ca}^{2+}$ channels, cold stress induces a transient $\mathrm{Ca}^{2+}$ influx into the cytosol (Figure 1a). Two Arabidopsis calcium-permeable mechano-sensitive channels, AtMCA1 and AtMCA2, are involved in a cold-induced increase in $\left[\mathrm{Ca}^{2+}\right]_{\mathrm{cyt}}$ and cold stress tolerance [22]. A cold sensor OsCOLD1 is the novel PM and endoplasmic reticulum (ER)-located protein, which interacted with $\alpha$ subunit 1 of the G protein (RGA1), enhancing the calcium transients in the cytosol in cold signal transduction in rice [23]. Two cyclic nucleotide-gated channels, OsCNGC14 and OsCNGC16, mediate the calcium signaling and promote chilling tolerance in rice seedlings. Their homologous proteins AtCNGC2 and AtCNGC4 in Arabidopsis promote chilling growth and freezing tolerance [24]. OsCNGC9 positively regulates chilling tolerance by mediating cytoplasmic calcium signaling in rice [25] (Figure 1b). Therefore, calcium channels play a central role in cold stress sensing in Arabidopsis and rice.

On the other hand, a new calcium sensor synaptotagmin without the EF-hand motif, AtSYT1, localized to the PM and ER, participates in the exocytosis process in the calciumdependent pathway under freezing stress in Arabidopsis [26] (Figure 1a). In rice, thirteen SYT homologous N-terminal-TM-C2 domain proteins (OsNTMC2) have been annotated [27]. However, the function of OsNTMC2 in vesicle trafficking and PM repair in cold stress response awaits further investigations.

Many receptor-like protein kinases, such as two-component histidine kinases, RLKs, and G-protein associated kinases, have played pivotal roles in cold stress sensing in Arabidopsis and rice. Two-component signaling systems, AHK2/3, AHP2/3/5, and ARR7, mediate the cold stress signaling through inhibiting ABA signaling [28,29]. Besides, AtCRLK1 binds to calcium and calmodulin (CaM), interacts with phosphorylates AtMEKK1 in freezing signaling and tolerance [30]. Moreover, AtCRPK1 phosphorylates 14-3-3 $\lambda$ which shuttles from the cytosol to the nucleus, then interacts with and destabilizes the CBFs in freezing stress tolerance [31]. In addition, AtPXL1 interacts with and phosphorylates histidine-rich dehydrin1 (AtHIRD1) and a light-harvesting protein complex I (AtLHCA1) to positively regulate cold and heat stress tolerances during the germination stage [32]. 
a



Freezing stress in Arabidopsis PM

b

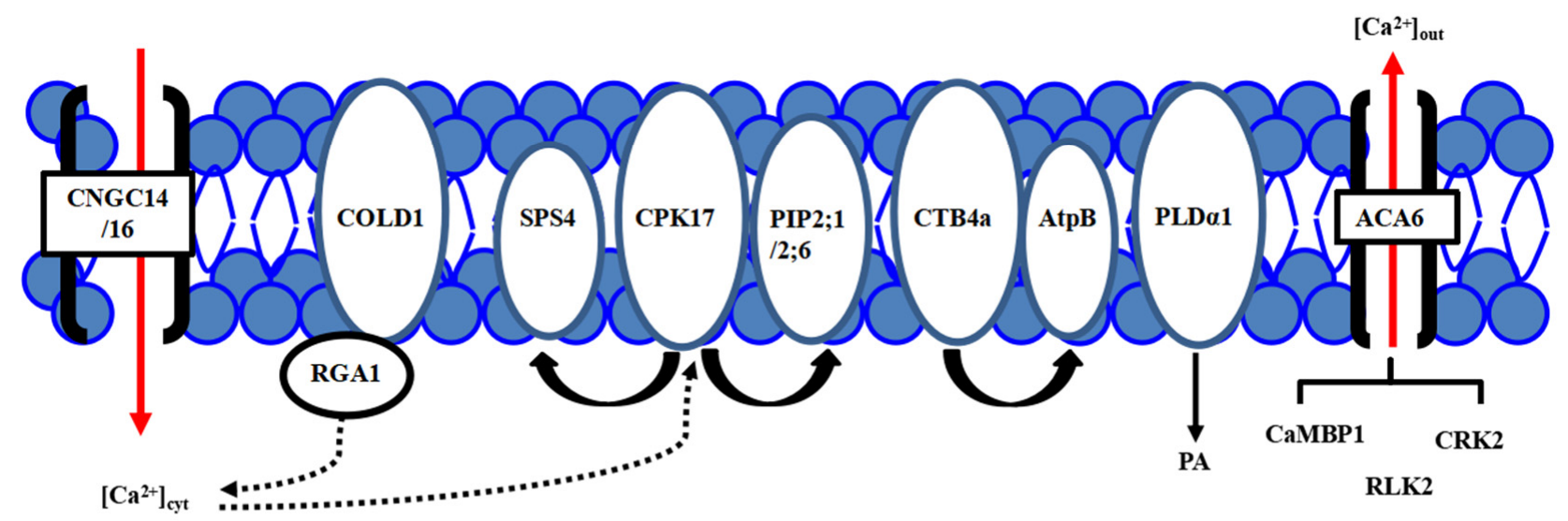

Chilling stress in rice PM

Figure 1. Plasma membrane-localized proteins perceive the cold stress signals in Arabidopsis and rice. (a) In Arabidopsis, freezing stress initiates the PM rigidification, PM-associated calcium channels MCA1/2, calcium sensor SYT1 and kinases including CRLK1, AtHK1/2/3, and CRPK1, as well as PM-localized PXL1, participate in primary cold stress sensing and perception. (b) In rice, chilling stress initiates the PM rigidification, many PM-associated proteins, including calcium channels ACA6, CNGC14/16, phospholipidase PLD $\alpha 1$, aquaporin proteins PIP2;1/PIP2;6, G-protein-associated cold sensor COLD1 and kinases GT4a and CPK17, participate in primary cold stress sensing and perception. However, a specific calcium channel for calcium influx is still not known.

In rice, there are several identified PM-localized kinases involved in cold stress perception. OsACA6, a PM Ca ${ }^{2+}$-ATPase, interacts with CaM-binding protein OsCaMBP1, calcium-dependent protein kinase (CDPK)-related kinase OsCRK2, and receptor-like kinase (RLK) OsRLK2 [33]. PM-localized OsCPK17 interacts with and phosphorylates the sucrosephosphate synthase OsSPS4 and aquaporin OsPIP2;1/OsPIP2;6, can enhance the cold stress tolerance in rice [34](Figure 1b). CTB4a, a conserved leucine-rich repeat receptor-like kinase, interacts with a beta subunit of adenosine triphosphate (ATP) synthase AtpB and improves the yield under cold stress [35]. Interestingly, the protein level of phospholipase D $\alpha 1$ (OsPLD $\alpha 1$ ) increases at one minute after cold treatment. It activates OsMPK6 and OsSIZ1, followed by the regulations of OsDREB1s expression in cold signaling [36] (Figure 1b). Therefore, there is much convergence of primary PM-located protein kinases in cold stress perceptions between Arabidopsis and rice. 


\section{Cold Stress Signal Transduction Mechanisms in Arabidopsis and Rice}

Following the cold stress perceptions, cold stress signal transduction events occur in the cytosol and nucleus of plant cells. The second messengers, such as $\mathrm{Ca}^{2+}$ and reactive oxygen species (ROS), transmit the external cold signals to intracellular signaling systems. Progress has been made in calcium signaling, phospholipid signaling, MAPK cascade signaling, and ROS signaling in the past decades. Here, we compare the recent advances in signal transduction pathways of freezing stress in Arabidopsis and chilling stress in rice (Figures 2 and 3), highlighting the divergence and convergence in cold stress in both plant species.

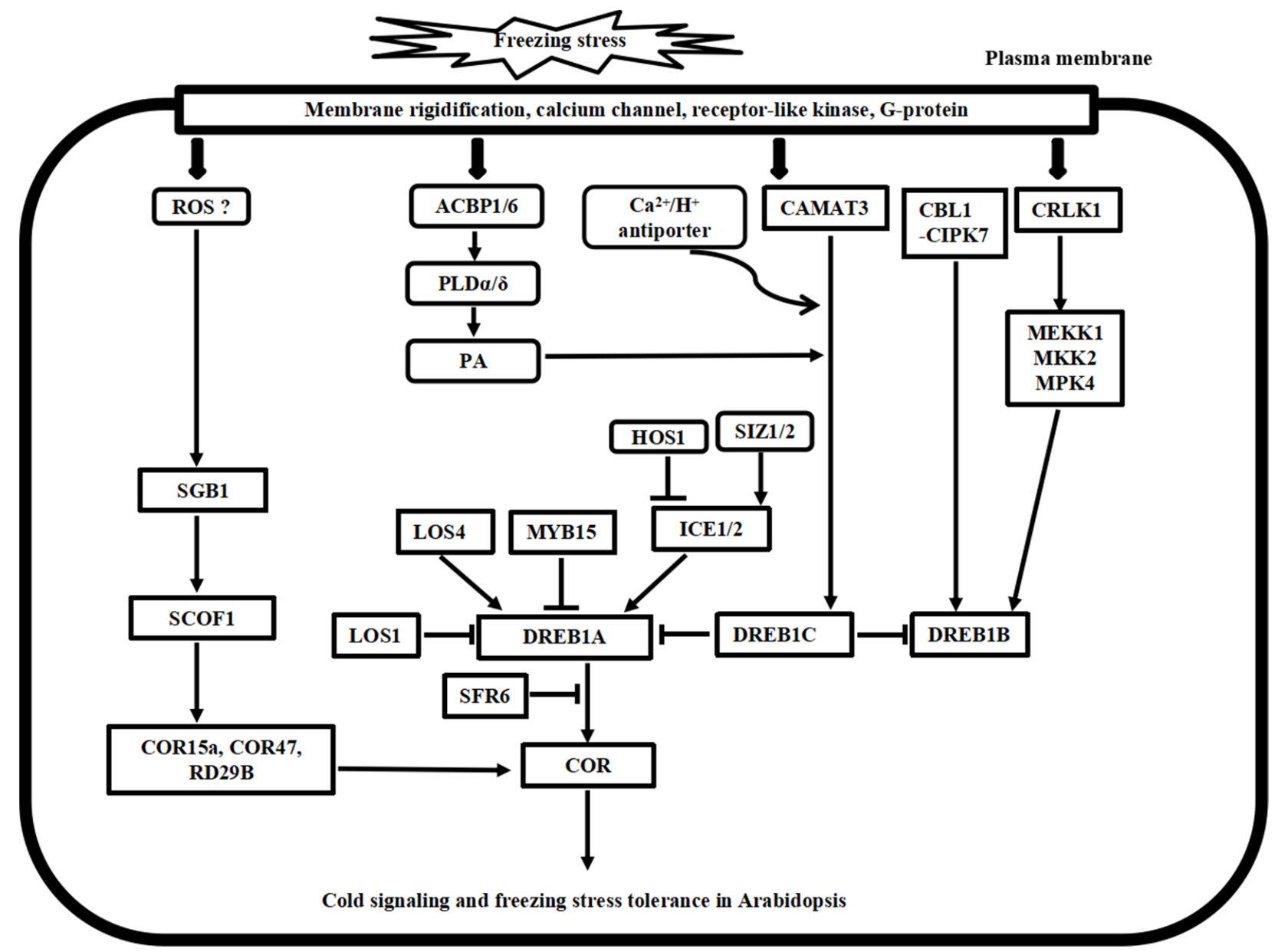

Figure 2. Putative model of cold stress signaling networks toward freezing stress tolerance in Arabidopsis. The coldinduced calcium signature in the cytosol is recognized by the calcium sensor proteins, including CaM, CDPK, CBL1/CIPK7, and CAMAT3, as well as the bZIP transcription factor SGB1 pathway. In addition, CRLK1-MEK1-MKK1/2-MPK4/6 cascade, ROS signaling, and phospholipid signaling work together to regulate cold stress signaling, and many ICE1-DREB transcription activators and repressors have been identified to regulate the COR gene expressions, finally leading to freezing tolerance in Arabidopsis. 


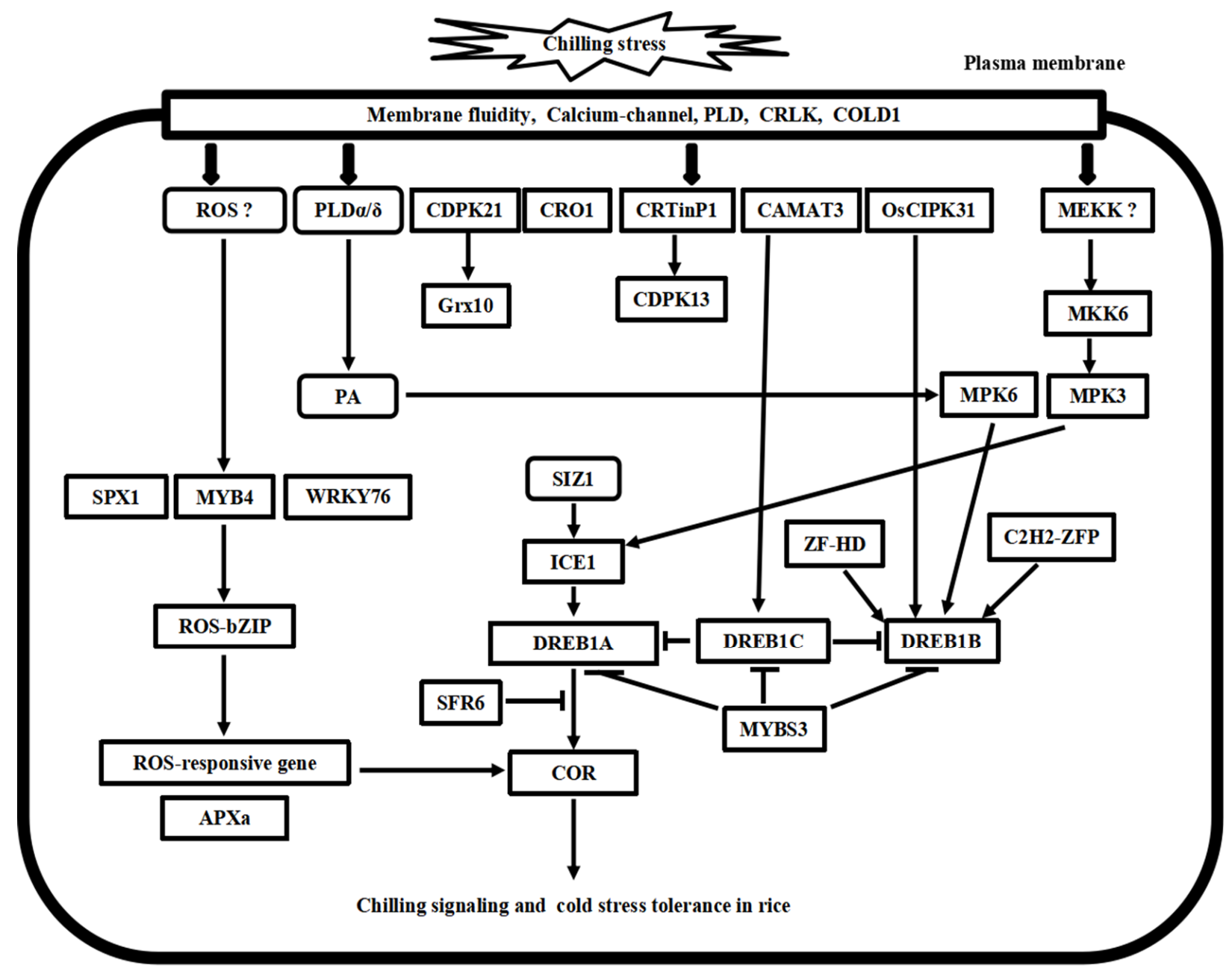

Figure 3. Putative model of chilling stress signaling networks toward cold stress tolerance in rice. There are at least four chilling stress signaling pathways in rice. MYB4-ROS-bZIP cascade is involved in the ROS signaling process. MKK6-MP3 cascade and phospholipid signaling work with calcium signaling concomitantly in chilling stress signaling in rice. ICE1DREB transcriptional regulatory cascade is conserved in the Arabidopsis and rice. Furthermore, these pathways' upstream and downstream signal transducer proteins play cooperative and regulatory roles in cold stress tolerance in rice.

\subsection{Calcium Signaling}

Calcium influx into the cytosol is an early event in cold stress $[6,17]$. This transient elevation in calcium concentration is also called intracellular calcium signature. Calcium influx is primarily sensed by the calcium sensor proteins, containing the helix-loop-helix domain with the EF-hand motif. In plants, calcium sensors include four major classes: $\mathrm{CaM} / \mathrm{CaM}$-like protein (CML), calcium-dependent protein kinase (CDPK or CPK), calcineurin B-like (CBL) protein, and CBL-interacting protein kinase (CIPK). In addition, a small annexin family has been identified as a calcium sensor to cold stress response in Arabidopsis.

In Arabidopsis, overexpression of AtCaM3 hinders the cold induction of $R D 29 A$ and KIN1, and the AtCaM4 negatively regulates freezing tolerance by interacting with a CaMbinding protein PATL1 [37]. AtCBL1 interacts with AtCIPK7 and binds to the DREB core element of $C O R$ promoters to negatively regulate freezing tolerance [38]. CaM-binding transcription activator protein CAMTA3 binds to the conserved CG-1 element in the CBF2 promoter, regulating CBF2 expression in cold stress signaling [39]. A vacuolar $\mathrm{Ca}^{2+} / \mathrm{H}^{+}$ antiporter AtCAX1 enhances the DREB1 transcription in cold acclimation response [40]. Recently, an AtOST1-AtANN1cascade was found to regulate calcium signaling in the CBF1-dependent manner to enhance freezing tolerance in Arabidopsis [41]. This evidence 
demonstrated the negative and positive regulations of calcium sensors to freezing tolerance in Arabidopsis.

In rice, a CaM-like protein OsCML16 and its six putative targets have been identified to be involved in cold stress response in rice [42]. However, there is no report about the role of OsCaMs in cold stress signaling. OsCDPK7 enhances cold stress tolerance by the increased accumulation of a putative target gene rab16A $[43,44]$. OsCDPK13 enhances cold stress tolerance by activating a ubiquitin-like nuclear protein OsCRTintP1, calreticulin interacting protein $1[45,46]$. OsCPK24 interacts with and phosphorylates OsGrx10, a glutathione-dependent thioltransferase, in cold stress response [47]. Overexpression of OsCIPK3, a CBL-interacting protein kinase, improves cold stress tolerance [48]. It is worth mentioning that OsCIPK31 is strongly induced by cold and salt stress and interacts with AtCBL3, suggesting the convergence of CBL/CIPK pathways in cold stress signaling Arabidopsis and rice [49]. As described above, the CaM-associated signaling pathways in cold stress signaling wait for further confirmations in Arabidopsis and rice.

\subsection{Phospholipid Signaling}

An increasing number of studies have shown that the metabolism of the membrane lipids plays an important role in the temperature stress response in plants. In Arabidopsis, in a few seconds after cold exposure, diacylglycerol kinase (DGK) is activated to converse diacylglycerol (DAG) into phosphatidic acid (PA), followed by a change in membrane fluidity [50]. Overexpression of a PM-bound phospholipase gene PLD $\delta$ enhances freezing tolerance in rice seedlings [51]. Suppressed expression of PLD $\alpha 1$ results in a significant increase in freezing tolerance [52]. Acyl-coenzyme A: diacylglycerol acyltransferase DGAT1 enhances freezing tolerance via CBF2 regulon and NADPH oxidase RbohD (respiratory burst oxidase homolog D)-dependent $\mathrm{H}_{2} \mathrm{O}_{2}$ production in Arabidopsis [53]. The acylcoenzyme A-binding protein (ACBP) family has six members (AtACBP1-6) in Arabidopsis. Overexpression of $A t A C B P 6$ enhances freezing tolerance by activating PLD $\delta$ to decrease phosphatidylcholine (PC) levels and accumulate PA [54]. Overexpression of AtACBP1 increases freezing sensitivity via the expression of $P L D \alpha 1$ and $P L D \delta$ and maintains a membrane-associated PA pool [55]. Further, a temperature-induced lipid pathway has been demonstrated. The FAD2, FAD5 and ACT1 have been identified as the key enzymes in influencing fatty acid flux between the eukaryotic and prokaryotic pathways cold stress response in Arabidopsis [56].

In plants, glycerol-3-phosphate acyltransferase (GPAT) of chloroplasts is a key enzyme to catalyze transferring the acyl group of acyl-(acyl-carrier-protein) (ACP) into the sn-1 position of glycerol 3-phosphate in the first step of glycerolipid biosynthesis in chloroplasts. Ectopic overexpressing of AtGPAT in rice largely induces the unsaturation of fatty acids and chilling tolerance of photosynthesis under low temperature [57]. In rice, the $\omega-3$ fatty acid (FA) desaturase (FAD8) mutant does not acclimate to cold stress [58]. OsPLD $\alpha 1$ increases the levels of PA that bind to OsMPK6 in cold signaling and tolerance [36]. Interestingly, comparative glycerolipidomics analysis of freezing stress $\left(-6^{\circ} \mathrm{C}\right.$ and $\left.-12{ }^{\circ} \mathrm{C}\right)$ in Arabidopsis and chilling stress $\left(4^{\circ} \mathrm{C}\right.$ and $\left.10^{\circ} \mathrm{C}\right)$ in rice has illustrated that Arabidopsis has a higher double bond index (DBI) and lower average acyl chain length (ACL) than rice under cold stress condition [59]. Accordingly, glycerolipid metabolism and signaling show great potentials in applying cold stress tolerance engineering in Arabidopsis and rice.

\subsection{MAPK Cascade Signaling}

In plants, the MAPK cascade consists of three sequentially phosphorylating and activating components, a MAP kinase kinase kinase (MEKK/MAPKKK), a MAP kinase kinase (MEK/MAPKK), and a MAP kinase (MPK/MAPK). MAPKs phosphorylate various downstream substrates, including transcription factors, protein kinases, phospholipases, and cytoskeleton-associated proteins, finally leading to the activation of specific gene expressions under stress conditions [60]. 
In Arabidopsis, MAPKKK protein AtANP1 initiates a phosphorylation cascade with AtMPK3 under cold stress [61]. The complete cascade AtCRLK1-AtMEKK1-AtMKK2AtMPK4/ 6 has been established to positively regulate freezing tolerance [62]. Recently, AtMPK6 is found to phosphorylate AtMYB15 to reduce the binding affinity of AtCBF3 and freezing tolerance [63]. AtMPK3 and AtMPK6 phosphorylate AtICE1 to promote its degradation, thereby negatively regulate freezing tolerance [64]. AtMPK6 phosphorylates AtMYB5 to positively regulate freezing tolerance [63]. However, the AtMEKK1-AtMKK1/2AtMPK 4 cascade promotes freezing tolerance by antagonizing the AtMPK3/6 pathway [65]. These results indicate that AtMPK3, AtMPK4, and AtMPK6 proteins cooperatively regulate freezing tolerance in Arabidopsis.

In rice, there is not identified complete MAPK pathway involved in cold stress signaling until now. Our previous study established that the OsMKK6-OsMPK3 cascade modulates chilling signaling and tolerance in rice [66]. OsMPK3 phosphorylates and stabilizes OsICE1, which directly transactivates the expression of OsTPP1, thereby positively regulating chilling tolerance [67]. Moreover, PA binds to OsMPK6 and mediates chilling stress signaling and tolerance [36]. Therefore, these results have demonstrated a divergence in MAPK signaling pathways and regulation network in cold stress response in Arabidopsis and rice.

\subsection{ROS Signaling}

Under cold stress, excess ROS is produced and brings about oxidative damage and cold stress response in plant cells. In Arabidopsis, AtMEKK1-AtMKK2-AtMPK4/ AtMPK6 cascade regulates the ROS-scavenging enzymes to maintain redox homeostasis under cold stress [62]. Overexpression of a ROS-regulated $\mathrm{C}_{2} \mathrm{H}_{2}$ zinc finger transcription factor AtZAT12 decreases the expressions of AtCBF1/2/3 genes under cold stress [68]. In addition, AtHAP5A, a heme-associated protein, positively modulates the freezing resistance by binding AtXTH21 and inhibits ROS accumulation under freezing stress [69]. Stromal and thylakoid-bound ascorbate peroxidases SAPX and tAPX trigger COR15A, PAL1, and CHS expressions under cold stress [70]. AtTrx-h2 regulates the expressions of COR genes under freezing stress [71].

$\mathrm{H}_{2} \mathrm{O}_{2}$ levels are increased within $1.5 \mathrm{~h}$ of $10{ }^{\circ} \mathrm{C}$ stress in rice seedlings [72]. A subset of 121 early-response genes was upregulated during the initial $24 \mathrm{~h}$ of $10{ }^{\circ} \mathrm{C}$ stress [73]; Among them, four are transcription factor genes, including ROS-bZIP1 and asl/ocs-like element-containing genes. A hypothetical model of ROS-mediated regulon (ROS-bZIPas1/ocs) is assembled independent of CBF/DREB- or ABA-mediated regulons in cold stress response [72,73]. Comparative metabolomics analysis of indica (9311) and japonica (Nipponbare) varieties revealed a ROS-dominated dynamic model involved in chilling stress adaptation and tolerance in rice [74]. Overexpression of OsZFP245 enhances cold stress tolerance by regulating proline levels and ROS-scavenging activities in rice seedlings [75]. Overexpressing OsAPX1 prevents the over-accumulation of $\mathrm{H}_{2} \mathrm{O}_{2}$ and reduces lipid peroxidation in the spikelet tissues at the booting stage of rice [76]. Natural variation reveals that OsSAP16 controls low-temperature germination in rice [77]. Therefore, there exist specific and different pathways of ROS-mediated cold signaling in rice.

\section{ICE-CBF Transcriptional Cascade}

ICE and CBF homologs are highly conserved in Arabidopsis and rice. In Arabidopsis, ICE-CBF transcriptional cascade has been established as the main regulatory response toolkit to cold signaling and freezing tolerance [78]. There are several identified positive and negative regulators, including HK2/3, CAMTA3, OST1, HOS1, and SIZ1/2 for ICE1, ICE1 for CBF3, MYB15 for CBFs, and SRF6 for COR [79-81]. ICE1 binds toe CBF3 promoter and induces the $C B F 3$ expression in cold stress signaling [82]. Overexpression of ICE2 induces the expression of CBF1 and enhances freezing tolerance [83]. A RING-finger ubiquitin E3 ligase, HOS1, interacts with ICE1 and targets for polyubiquitylation and proteolysis of ICE1 after $12 \mathrm{~h}$ of cold stress [79]. SIZ1 catalyzes sumoylation of ICE1 during 
cold acclimation and thus reduces the ICE1 polyubiquitylation [80]. OsSFR6 enhances freezing tolerance in Arabidopsis [84]. However, there are no such reports of cold signaling in rice.

Furthermore, OST1 phosphorylates and stabilizes ICE1 to enhance freezing tolerance [85]. ICE1 interacts with and negatively regulates the expression of MYB15 during cold acclimation [81]. EIN3, an ethylene-insensitive 3 gene, negatively regulates the expressions of CBFs and type-A ARRs [86]. Two repressors of jasmonate acid (JA) signaling, JAZ1, and JAZ4, interact with and suppress ICE1 and ICE2 transcription activity, finally repressing the $C B F 3$ expression and freezing tolerance [87]. ZAT12 regulon inhibits the CBF cold-response regulatory pathway [68]. CAMTA3, a CaM-binding transcription factor, binds to the CG-1 element in the promoter of ZAT12 under cold stress [28].

In rice, transcript levels of OsICE1 and OsICE2 remain constant during cold stress, indicating that they are posttranslationally modified under cold stress [88]. Ectopic overexpression of OsICE1 and OsICE2 in Arabidopsis imparts freezing tolerance by inducing CBF expressions [89]. OsDREB1A and OsDREB1B transcripts are induced within $40 \mathrm{~min}$ after cold stress. Overexpressing OsDREB1A increases chilling stress tolerance in rice [90]. Ectopic overexpression of OsDREB1A and OsDREB1B in Arabidopsis enhances the expressions of stress-inducible genes $r d 29 a$, cor15a, and $r d 17$ [91]. In particular, OsMYBS3 represses the transcriptional level of the OsDREB1-dependent cold response pathway in rice [92]. OsROC1 enhances the chilling tolerance by activating OsDREB1 in rice [93]. These results have revealed the convergence in the ICE-CBF cascade and divergence in the regulation of the ICE-CBF cascade in cold stress signaling in both species. As expected, new kinases, phosphatases, and transcriptional regulatory factors upstream and downstream of DREBs will integrate the convergent and divergent networks of cold stress signaling in Arabidopsis and rice.

\section{Light Modulates the Cold Stress Tolerance}

Cross talk between light signaling and cold signaling has been elucidated in the model plant Arabidopsis and tomato and cereals species [13]. For example, in Arabidopsis, there are five phytochromes isoforms phyA-E. By using Arabidopsis phys mutants, Franklin and Whitelam confirmed that phyB and D prevent the realization of FR-induced cold tolerance at $16{ }^{\circ} \mathrm{C}[94,95]$. Interestingly, phytochrome $\mathrm{A}$ and $\mathrm{B}$ function antagonistically to regulate cold stress via abscisic acid (ABA)-dependent jasmonate signaling in tomatoes [96]. Similar results have been obtained in wheat and barley [97]. In barley, the light-regulated signal transduction system was reported to connect the circadian clock, phospholipid signaling

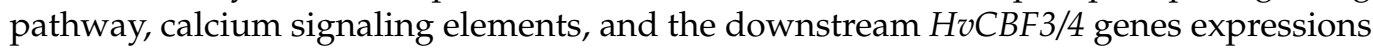
under cold stress [98].

In rice, phyB negatively regulates chilling tolerance. The phytochrome B-deficient mutant (phyB) shows the more stabilized chloroplast structure and higher unsaturated fatty acid (USFA) content in membrane lipids, thereby alleviating the chilling-induced photoinhibition. Moreover, expressions of genes associated with USFA syntheses such as OsFAD7 and OsFAD8 are higher in the phyB mutant than in the wild type, suggesting that OsFAD7 and OsFAD8 are the downstream genes of phyB [99]. On the other hand, phyB negatively regulates the OsDREB1 expression through interacting with OsPIL16 to reduce the membrane integrity under cold stress [100]. Therefore, phyB probably senses the red light signals and transduces the low-temperature signal together with a series of downstream genes, at least in part through changes in the composition and stability of cell membranes under cold stress. Nevertheless, there are many gaps to bridge between red light signal reception and cold stress response in plants.

\section{Downstream Response Pathways in the Arabidopsis Freezing Stress and Rice Chilling Stress}

The development of genetically engineered plants by the repression and overexpression of selected genes seems to be a viable option to hasten the breeding of cold stress tolerance-improved crop plants. Genetic engineering of cold stress tolerance was reviewed 
in crop and horticultural plants in 2011 [101]. The recent progress in freezing tolerant transgenic Arabidopsis and chilling tolerant transgenic rice has been updated (Tables 1 and 2). In Arabidopsis, engineering of freezing stress tolerance have been obtained through protein kinases and their associated proteins such as AtLCBK1 [102], AtBZR1 [103], AtCRF4 [104], ARR22 [105], and AtTCF1 [106]. Many transcription factors, such as bZIP, ZFP, WRKY, MYB, NAC, GT, DEAR, AP2, AREB, and ERF, have been applied to improve freezing stress tolerance. Furthermore, AtACBP6 [107] and AtLCBK1 [102] have been identified as positive regulators of freezing tolerance. Based on the four signaling pathways above, these engineered genes function downstream of phospholipid signaling, ROS signaling, and $\mathrm{CBF}$ regulon under freezing stress response (Table 1 ). Thus, these regulatory and functional proteins can adjust the balance of dehydration, detoxification, and metabolism under freezing stress in Arabidopsis, increasing the widespread distribution and adaptation to temperature stress in natural habitats.

Table 1. List of transgenic freezing stress Arabidopsis lines since 2011.

\begin{tabular}{|c|c|c|c|c|}
\hline Genes & Proteins & $\begin{array}{l}\text { Signaling } \\
\text { Pathways }\end{array}$ & $\begin{array}{c}\text { Freezing Stress } \\
\text { Regulation }\end{array}$ & References \\
\hline AtLCBK1 & long-chain base kinases & Phospholipid & Positive & [102] \\
\hline AtBZR1 & brassinazole-resistant 1 & CBF & Positive & [103] \\
\hline AtCRF4 & $\begin{array}{l}\text { cytokinin response } \\
\text { factor } 4\end{array}$ & CBF & Positive & {$[104]$} \\
\hline AtOST1 & open stomata 1 & CBF & Positive & [85] \\
\hline AtACBP6 & $\begin{array}{c}\text { Acyl-coenzyme } \\
\text { A-binding protein } 6 \\
\text { histidine }\end{array}$ & Phospholipid & Positive & [107] \\
\hline AHP2/3/5 & $\begin{array}{c}\text { phosphotransfer protein } \\
2 / 3 / 5\end{array}$ & CBF & Positive & [28] \\
\hline$A R R 22$ & $\begin{array}{l}\text { Arabidopsis response } \\
\text { regulator }\end{array}$ & CBF & Positive & [105] \\
\hline AtTCF1 & $\begin{array}{c}\text { Tolerant to Chilling and } \\
\text { Freezing }\end{array}$ & ROS & Negative & [106] \\
\hline AtVOZ2 & $\begin{array}{l}\text { vascular one zinc-finger } \\
\text { protein }\end{array}$ & ROS & Negative & [108] \\
\hline AtCCA1 & $\begin{array}{c}\text { circadian } \\
\text { clock-associated } 1\end{array}$ & $\mathrm{CBF}$ & Positive & [109] \\
\hline AtMYB96 & $\begin{array}{l}\text { MYB transcription } \\
\text { factor }\end{array}$ & CBF & Positive & [110] \\
\hline AtFTL1 & AP2 transcription factor & CBF & Positive & [111] \\
\hline AtPMEI13 & $\begin{array}{l}\text { pectin methyl-esterase } \\
\text { inhibitor }\end{array}$ & ROS & Negative & [112] \\
\hline AtSAG101 & lipase-like regulators & Phospholipid & Negative & [113] \\
\hline AtEDS1 & lipase-like regulators & Phospholipid & Negative & [113] \\
\hline AtPAD4 & lipase-like regulators & Phospholipid & Negative & [113] \\
\hline
\end{tabular}

In rice, a transgenic approach has been adopted to improve cold stress tolerance. We update the engineering cold stress-tolerant rice since 2011 (Table 2). Based on the functions of these genes in cold stress tolerance in rice, they can be divided into positive regulatory genes and negative regulatory genes. Positive regulatory genes include OsCAF1B [114], OsSHMT1 [115], OsUGT90A1 [116], OsPYL10 [117], OsRBGD3 [118], OsPYL3 [119], OsSAPK6 [120], OsPUB2/3 [121], OsRAN1 [122], OsRAN2 [123], OsZFP182 [124], OsCTZFP8 [125], OsbZIP46 [120], ONAC095 [126], OsNAC5 [127], OsWRKY76 [128], OsTERF2 [129] and OsMYB2 [130]. In addition, negative regulatory genes include OsMYB30 [131], OsbZIP52 [132], OsSPX1 [129] and OsWRKY45 [133]. Based on the four signaling pathways above, these engineered genes function downstream of ABA signaling, ROS signaling, and CBF regulon under chilling stress response in rice (Table 2). Therefore, these genes are responsible for ROS homeostasis, proton transport, pectin degradation, and trehalose biosynthesis under cold stress in rice. 
Table 2. List of transgenic chilling stress rice lines since 2011.

\begin{tabular}{|c|c|c|c|c|}
\hline Genes & Proteins & $\begin{array}{l}\text { Signaling } \\
\text { Pathways }\end{array}$ & $\begin{array}{c}\text { Chilling Stress } \\
\text { Regulation }\end{array}$ & References \\
\hline OsCAF1B & CCR4-associated factor 1 & ROS & Positive & [114] \\
\hline OsSHMT1 & $\begin{array}{c}\text { Serine } \\
\text { hydroxymethyltransferase }\end{array}$ & ROS & Positive & [115] \\
\hline OsUGT90A1 & UDP-glycosyltransferase & ROS & Positive & [116] \\
\hline OsPYL3 & pyrabactin resistance-like & $\mathrm{ABA}$ & Positive & [119] \\
\hline OsRBGD3 & $\begin{array}{l}\text { RNA-binding glycine-rich } \\
\text { protein }\end{array}$ & ABA & Positive & [118] \\
\hline OSPYL10 & ABA receptor 10 & $\mathrm{ABA}$ & Positive & [117] \\
\hline OsSAPK6 & $\begin{array}{l}\text { SNF-1 related protein } \\
\text { kinase } 2\end{array}$ & $\mathrm{ABA}$ & Positive & [120] \\
\hline OsPUB $2 / 3$ & U-box E3 Ub ligases & CBF & Positive & [121] \\
\hline OsRAN1 & small GTPase & ROS & Positive & [122] \\
\hline OsRAN2 & small GTPase & ROS & Positive & [123] \\
\hline OsZFP182 & $\begin{array}{l}\text { TFIIIA-type zinc finger } \\
\text { protein }\end{array}$ & ROS & Positive & [124] \\
\hline OsCTZFP8 & $\mathrm{C} 2 \mathrm{H} 2$ zinc finger protein & ROS & Positive & [125] \\
\hline OsbZIP46 & bZIP transcription factor & $\mathrm{ABA}$ & Positive & [120] \\
\hline OsbZIP52 & bZIP transcription factor & $\mathrm{ABA}$ & Negative & [132] \\
\hline ONAC095 & NAC transcription factor & ABA & Positive & [126] \\
\hline OsNAP & NAC transcription factor & $\mathrm{ABA}$ & Positive & [134] \\
\hline OsNAC5 & NAC transcript factor & ROS & Positive & [127] \\
\hline OsMBY30 & MYB transcription factor & ROS & Negative & [131] \\
\hline OsMYB2 & MYB transcription factor & ROS & Positive & [130] \\
\hline OsWRKY76 & WRKY transcript factor & ROS & Positive & [128] \\
\hline OsWRKY45 & WRKY transcript factor & ROS & Negative & [133] \\
\hline OsTERF2 & ethylene response factor & ROS & Positive & [88] \\
\hline OsSPX1 & SPX domain protein & ROS & Positive & [129] \\
\hline OsBURP16 & Polygalacturonase $1 \beta$ & ROS & Negative & [135] \\
\hline OsAOX1a & alternative oxidase 1 & ROS & Positive & [136] \\
\hline OsAPX2 & ascorbate peroxidase & ROS & Positive & [137] \\
\hline OsAPXa & ascorbate peroxidase & ROS & Positive & [76] \\
\hline OVP1 & V-PPase & ROS & Positive & [138] \\
\hline OsTPS1 & $\begin{array}{l}\text { trehalose-6-phosphate } \\
\text { synthase }\end{array}$ & $\mathrm{CBF}$ & Positive & [139] \\
\hline
\end{tabular}

\section{Conclusions and Perspectives}

This review analyzes the convergence in cold sensors PM-bound calcium channels and receptor-like protein kinases in cold stress sensing in Arabidopsis and rice. Identifying these proteins in calcium signaling and MAPK cascades will be helpful to strengthen the cold-induced perception mechanisms in Arabidopsis and rice. On the other hand, there is convergence in calcium signaling, MAPK cascade signaling, ICE-CBF transcriptional pathways, and divergence in phospholipid signaling and ROS signaling. These signaling pathways have evolved into distinctive and integrative networks in cold stress responses in both species.

In the future, regulon engineering will be a novel strategy by using a master regulatory switch to cause transcriptional changes in the cold response of rice [140]. An efficient engineering approach will be to generate constitutively active mutant genes, for example, by deleting the inhibitory domains of transcription factors or changing phosphorylation mimicking/depriving status in the signal transducers such as MAPK, MAPKK, or receptor kinases. Meanwhile, to prevent constitutive overexpression of cold-responsive genes from consuming extra energy and producing undesirable traits, tissue-specific and cold stressinducible promoters will be beneficial for the genetic improvement of cold tolerance in rice. Finally, a multi-genes site-specific assembly system will be developed. Elite constructs with 
multiple stress tolerant genes via CRISPR-Cas9 strategy should be designed to enhance rice crop productivity to cold stress.

Author Contributions: L.W. and G.X. conceived the idea and design of manuscript; X.W., S.L. and C.S. collected the references and summarized the data. X.W., L.W. and G.X. wrote the manuscript. L.W. and G.X. finalized the manuscript. All authors contributed to this article and approved the submitted version. All authors have read and agreed to the published version of the manuscript.

Funding: This work was granted by the Natural Science Foundation of Guangxi (grant no. 2020GXNSFDA238027), the National Natural Science Foundation of China (grant no. 31571583, $31771775,31171524)$.

Data Availability Statement: Not applicable.

Conflicts of Interest: The authors declare no conflict of interest.

\section{References}

1. Yan, S.P.; Zhang, Q.Y.; Tang, Z.C.; Su, W.A.; Sun, W.N. Comparative proteomic analysis provides new insights into chilling stress responses in rice. Mol. Cell Proteom. 2006, 5, 484-496. [CrossRef]

2. Uemura, M.; Joseph, R.A.; Steponkus, P.L. Cold acclimation of arabidopsis thaliana (effect on plasma membrane lipid composition and freeze-induced lesions). Plant Physiol. 1995, 109, 15-30. [CrossRef]

3. Thomashow, M.F. Plant cold acclimation: Freezing tolerance genes and regulatory mechanisms. Annu. Rev. Plant Physiol. Plant Mol. Biol. 1999, 50, 571-599. [CrossRef]

4. Fowler, S.; Thomashow, M.F. Arabidopsis transcriptome profiling indicates that multiple regulatory pathways are activated during cold acclimation in addition to the cbf cold response pathway. Plant Cell 2002, 14, 1675-1690. [CrossRef] [PubMed]

5. Yamaguchi-Shinozaki, K.; Shinozaki, K. Transcriptional regulatory networks in cellular responses and tolerance to dehydration and cold stresses. Annu. Rev. Plant Biol. 2006, 57, 781-803. [CrossRef]

6. Chinnusamy, V.; Zhu, J.K.; Sunkar, R. Gene regulation during cold stress acclimation in plants. Methods Mol. Biol. 2010, 639, 39-55. [CrossRef] [PubMed]

7. Miura, K.; Furumoto, T. Cold signaling and cold response in plants. Int. J. Mol. Sci. 2013, 14, 5312-5337. [CrossRef] [PubMed]

8. Knight, M.R.; Knight, H. Low-temperature perception leading to gene expression and cold tolerance in higher plants. New Phytol. 2012, 195, 737-751. [CrossRef]

9. Ding, Y.; Shi, Y.; Yang, S. Advances and challenges in uncovering cold tolerance regulatory mechanisms in plants. New Phytol. 2019, 222, 1690-1704. [CrossRef] [PubMed]

10. Lu, G.; Wu, F.Q.; Wu, W.; Wang, H.J.; Zheng, X.M.; Zhang, Y.; Chen, X.; Zhou, K.; Jin, M.; Cheng, Z.; et al. Rice ltg1 is involved in adaptive growth and fitness under low ambient temperature. Plant. J. 2014, 78, 468-480. [CrossRef]

11. Pareek, A.; Khurana, A.; Sharma, A.K.; Kumar, R. An overview of signaling regulons during cold stress tolerance in plants. Curr. Genom. 2017, 18, 498-511. [CrossRef] [PubMed]

12. Shi, Y.; Ding, Y.; Yang, S. Molecular regulation of cbf signaling in cold acclimation. Trends Plant. Sci. 2018, 23, 623-637. [CrossRef]

13. Lu, X.; Zhou, Y.; Fan, F.; Peng, J.; Zhang, J. Coordination of light, circadian clock with temperature: The potential mechanisms regulating chilling tolerance in rice. J. Integr. Plant. Biol. 2020, 62, 737-760. [CrossRef] [PubMed]

14. Xiong, L.; Schumaker, K.S.; Zhu, J.K. Cell signaling during cold, drought, and salt stress. Plant. Cell 2002, 14 (Suppl. 1), S165-S183. [CrossRef] [PubMed]

15. Murata, N.; Los, D.A. Membrane fluidity and temperature perception. Plant. Physiol. 1997, 115, 875-879. [CrossRef] [PubMed]

16. Sharma, A.; Isogai, M.; Yamamoto, T.; Sakaguchi, K.; Hashimoto, J.; Komatsu, S. A novel interaction between calreticulin and ubiquitin-like nuclear protein in rice. Plant. Cell Physiol. 2004, 45, 684-692. [CrossRef] [PubMed]

17. Penfield, S. Temperature perception and signal transduction in plants. New Phytol. 2008, 179, 615-628. [CrossRef] [PubMed]

18. McClung, C.R.; Davis, S.J. Ambient thermometers in plants: From physiological outputs towards mechanisms of thermal sensing. Curr. Biol. 2010, 20, R1086-R1092. [CrossRef]

19. Monroy, A.F.; Dhindsa, R.S. Low-temperature signal transduction: Induction of cold acclimation-specific genes of alfalfa by calcium at 25 degrees c. Plant. Cell 1995, 7, 321-331.

20. Knight, H.; Trewavas, A.J.; Knight, M.R. Cold calcium signaling in arabidopsis involves two cellular pools and a change in calcium signature after acclimation. Plant. Cell 1996, 8, 489-503. [CrossRef]

21. Kiegle, E.; Moore, C.A.; Haseloff, J.; Tester, M.A.; Knight, M.R. Cell-type-specific calcium responses to drought, salt and cold in the arabidopsis root. Plant. J. 2000, 23, 267-278. [CrossRef]

22. Mori, K.; Renhu, N.; Naito, M.; Nakamura, A.; Shiba, H.; Yamamoto, T.; Suzaki, T.; Iida, H.; Miura, K. Ca(2+)-permeable mechanosensitive channels mca1 and mca2 mediate cold-induced cytosolic ca(2+) increase and cold tolerance in arabidopsis. Sci. Rep. 2018, 8, 550. [CrossRef]

23. Ma, Y.; Dai, X.; Xu, Y.; Luo, W.; Zheng, X.; Zeng, D.; Pan, Y.; Lin, X.; Liu, H.; Zhang, D. Cold1 confers chilling tolerance in rice. Cell 2015, 160, 1209-1221. [CrossRef] 
24. Cui, Y.; Lu, S.; Li, Z.; Cheng, J.; Hu, P.; Zhu, T.; Wang, X.; Jin, M.; Wang, X.; Li, L.; et al. Cyclic nucleotide-gated ion channels 14 and 16 promote tolerance to heat and chilling in rice. Plant. Physiol. 2020, 183, 1794-1808. [CrossRef]

25. Wang, J.; Ren, Y.; Liu, X.; Luo, S.; Zhang, X.; Liu, X.; Lin, Q.; Zhu, S.; Wan, H.; Yang, Y.; et al. Transcriptional activation and phosphorylation of oscngc9 confer enhanced chilling tolerance in rice. Mol. Plant. 2021, 14, 315-329. [CrossRef]

26. Yamazaki, T.; Kawamura, Y.; Minami, A.; Uemura, M. Calcium-dependent freezing tolerance in arabidopsis involves membrane resealing via synaptotagmin syt1. Plant. Cell 2008, 20, 3389-3404. [CrossRef]

27. Huang, R.; Zhao, J.; Liu, J.; Wang, Y.; Han, S.; Zhao, H. Genome-wide analysis and expression profiles of ntmc2 family genes in oryza sativa. Gene 2017, 637, 130-137. [CrossRef] [PubMed]

28. Jeon, J.; Kim, J. Arabidopsis response regulator1 and arabidopsis histidine phosphotransfer protein2 (ahp2), ahp3, and ahp5 function in cold signaling. Plant. Physiol. 2013, 161, 408-424. [CrossRef]

29. Jeon, J.; Kim, N.Y.; Kim, S.; Kang, N.Y.; Novak, O.; Ku, S.J.; Cho, C.; Lee, D.J.; Lee, E.J.; Strnad, M.; et al. A subset of cytokinin two-component signaling system plays a role in cold temperature stress response in arabidopsis. J. Biol. Chem. 2010, 285, 23371-23386. [CrossRef]

30. Yang, T.; Shad Ali, G.; Yang, L.; Du, L.; Reddy, A.S.; Poovaiah, B.W. Calcium/calmodulin-regulated receptor-like kinase crlk1 interacts with mekk1 in plants. Plant. Signal. Behav. 2010, 5, 991-994. [CrossRef] [PubMed]

31. Liu, Z.; Jia, Y.; Ding, Y.; Shi, Y.; Li, Z.; Guo, Y.; Gong, Z.; Yang, S. Plasma membrane crpk1-mediated phosphorylation of 14-3-3 proteins induces their nuclear import to fine-tune cbf signaling during cold response. Mol. Cell 2017, 66, 117-128.e5. [CrossRef] [PubMed]

32. Jung, C.G.; Hwang, S.G.; Park, Y.C.; Park, H.M.; Kim, D.S.; Park, D.H.; Jang, C.S. Molecular characterization of the cold- and heat-induced arabidopsis pxl1 gene and its potential role in transduction pathways under temperature fluctuations. J. Plant. Physiol. 2015, 176, 138-146. [CrossRef]

33. Kamrul Huda, K.M.; Akhter Banu, M.S.; Yadav, S.; Sahoo, R.K.; Tuteja, R.; Tuteja, N. Salinity and drought tolerant osaca6 enhances cold tolerance in transgenic tobacco by interacting with stress-inducible proteins. Plant. Physiol. Biochem. 2014, 82, 229-238. [CrossRef]

34. Almadanim, M.C.; Alexandre, B.M.; Rosa, M.T.; Sapeta, H.; Leitão, A.E.; Ramalho, J.C.; Lam, T.T.; Negrão, A.; Abreu, I.A.; Oliveira, M.M. Rice calcium-dependent protein kinase oscpk17 targets plasma membrane intrinsic protein and sucrose-phosphate synthase and is required for a proper cold stress response. Plant. Cell Environ. 2017, 40, 1197-1213. [CrossRef]

35. Zhang, Z.; Li, J.; Pan, Y.; Zhou, L.; Shi, H.; Zeng, Y.; Guo, H.; Yang, S.; Zheng, W.; Yu, J.; et al. Natural variation in ctb4a enhances rice adaptation to cold habitats. Nat. Commun. 2017, 8, 14788. [CrossRef]

36. Huo, C.; Zhang, B.; Wang, H.; Wang, F.; Liu, M.; Gao, Y.; Zhang, W.; Deng, Z.; Sun, D.; Tang, W. Comparative study of early cold-regulated proteins by two-dimensional difference gel electrophoresis reveals a key role for phospholipase dalpha1 in mediating cold acclimation signaling pathway in rice. Mol. Cell Proteom. 2016, 15, 1397-1411. [CrossRef]

37. Chu, M.; Li, J.; Zhang, J.; Shen, S.; Li, C.; Gao, Y.; Zhang, S. Atcam4 interacts with a sec14-like protein, patl1, to regulate freezing tolerance in arabidopsis in a cbf-independent manner. J. Exp. Bot. 2018, 69, 5241-5253. [CrossRef]

38. Huang, C.; Ding, S.; Zhang, H.; Du, H.; An, L. Cipk7 is involved in cold response by interacting with cbl1 in arabidopsis thaliana. Plant. Sci. 2011, 181, 57-64. [CrossRef]

39. Doherty, C.J.; Van Buskirk, H.A.; Myers, S.J.; Thomashow, M.F. Roles for arabidopsis camta transcription factors in cold-regulated gene expression and freezing tolerance. Plant. Cell 2009, 21, 972-984. [CrossRef] [PubMed]

40. Catala, R.; Santos, E.; Alonso, J.M.; Ecker, J.R.; Martinez-Zapater, J.M.; Salinas, J. Mutations in the ca2+/h+ transporter cax1 increase cbf/dreb1 expression and the cold-acclimation response in arabidopsis. Plant. Cell 2003, 15, 2940-2951. [CrossRef] [PubMed]

41. Liu, Q.; Ding, Y.; Shi, Y.; Ma, L.; Wang, Y.; Song, C.; Wilkins, K.A.; Davies, J.M.; Knight, H.; Knight, M.R.; et al. The calcium transporter annexin1 mediates cold-induced calcium signaling and freezing tolerance in plants. EMBO J. 2021, 40, e104559. [CrossRef] [PubMed]

42. Yang, J.; Liu, S.; Ji, L.; Tang, X.; Zhu, Y.; Xie, G. Identification of novel oscml16 target proteins and differential expression analysis under abiotic stresses in rice. J. Plant. Physiol. 2020, 249, 153165. [CrossRef] [PubMed]

43. Saijo, Y.; Hata, S.; Kyozuka, J.; Shimamoto, K.; Izui, K. Over-expression of a single ca2+-dependent protein kinase confers both cold and salt/drought tolerance on rice plants. Plant. J. 2000, 23, 319-327. [CrossRef] [PubMed]

44. Saijo, Y.; Kinoshita, N.; Ishiyama, K.; Hata, S.; Kyozuka, J.; Hayakawa, T.; Nakamura, T.; Shimamoto, K.; Yamaya, T.; Izui, K. A $\mathrm{ca}(2+)$-dependent protein kinase that endows rice plants with cold- and salt-stress tolerance functions in vascular bundles. Plant. Cell Physiol. 2001, 42, 1228-1233. [CrossRef]

45. Abbasi, F.; Onodera, H.; Toki, S.; Tanaka, H.; Komatsu, S. Oscdpk13, a calcium-dependent protein kinase gene from rice, is induced by cold and gibberellin in rice leaf sheath. Plant. Mol. Biol. 2004, 55, 541-552. [CrossRef] [PubMed]

46. Komatsu, S.; Yang, G.; Khan, M.; Onodera, H.; Toki, S.; Yamaguchi, M. Over-expression of calcium-dependent protein kinase 13 and calreticulin interacting protein 1 confers cold tolerance on rice plants. Mol. Genet. Genom. 2007, 277, 713-723. [CrossRef]

47. Liu, Y.; Xu, C.; Zhu, Y.; Zhang, L.; Chen, T.; Zhou, F.; Chen, H.; Lin, Y. The calcium-dependent kinase oscpk24 functions in cold stress responses in rice. J. Integr. Plant. Biol. 2018, 60, 173-188. [CrossRef]

48. Xiang, Y.; Huang, Y.; Xiong, L. Characterization of stress-responsive cipk genes in rice for stress tolerance improvement. Plant. Physiol. 2007, 144, 1416-1428. [CrossRef] 
49. Kim, K.N.; Lee, J.S.; Han, H.; Choi, S.A.; Go, S.J.; Yoon, I.S. Isolation and characterization of a novel rice ca2+-regulated protein kinase gene involved in responses to diverse signals including cold, light, cytokinins, sugars and salts. Plant. Mol. Biol. 2003, 52, 1191-1202. [CrossRef]

50. Vaultier, M.N.; Cantrel, C.; Vergnolle, C.; Justin, A.M.; Demandre, C.; Benhassaine-Kesri, G.; Cicek, D.; Zachowski, A.; Ruelland, E. Desaturase mutants reveal that membrane rigidification acts as a cold perception mechanism upstream of the diacylglycerol kinase pathway in arabidopsis cells. FEBS Lett. 2006, 580, 4218-4223. [CrossRef]

51. Li, W.; Li, M.; Zhang, W.; Welti, R.; Wang, X. The plasma membrane-bound phospholipase ddelta enhances freezing tolerance in arabidopsis thaliana. Nat. Biotechnol. 2004, 22, 427-433. [CrossRef]

52. Rajashekar, C.B.; Zhou, H.E.; Zhang, Y.; Li, W.; Wang, X. Suppression of phospholipase dalpha1 induces freezing tolerance in arabidopsis: Response of cold-responsive genes and osmolyte accumulation. J. Plant. Physiol. 2006, 163, 916-926. [CrossRef]

53. Tan, W.J.; Yang, Y.C.; Zhou, Y.; Huang, L.P.; Xu, L.; Chen, Q.F.; Yu, L.J.; Xiao, S. Diacylglycerol acyltransferase and diacylglycerol kinase modulate triacylglycerol and phosphatidic acid production in the plant response to freezing stress. Plant. Physiol. 2018, 177, 1303-1318. [CrossRef]

54. Chen, Q.F.; Xiao, S.; Chye, M.L. Overexpression of the arabidopsis 10-kilodalton acyl-coenzyme a-binding protein acbp6 enhances freezing tolerance. Plant. Physiol. 2008, 148, 304-315. [CrossRef] [PubMed]

55. Du, Z.Y.; Chen, M.X.; Chen, Q.F.; Gu, J.D.; Chye, M.L. Expression of arabidopsis acyl-coa-binding proteins atacbp1 and atacbp4 confers pb(ii) accumulation in brassica juncea roots. Plant. Cell Env. 2015, 38, 101-117. [CrossRef]

56. Li, Q.; Zheng, Q.; Shen, W.; Cram, D.; Fowler, D.B.; Wei, Y.; Zou, J. Understanding the biochemical basis of temperature-induced lipid pathway adjustments in plants. Plant. Cell 2015, 27, 86-103. [CrossRef]

57. Ariizumi, T.; Kishitani, S.; Inatsugi, R.; Nishida, I.; Murata, N.; Toriyama, K. An increase in unsaturation of fatty acids in phosphatidylglycerol from leaves improves the rates of photosynthesis and growth at low temperatures in transgenic rice seedlings. Plant. Cell Physiol. 2002, 43, 751-758. [CrossRef]

58. Tovuu, A.; Zulfugarov, I.S.; Wu, G.X.; Kang, I.S.; Kim, C.; Moon, B.Y.; An, G.; Lee, C.H. Rice mutants deficient in omega-3 fatty acid desaturase (fad8) fail to acclimate to cold temperatures. Plant. Physiol. Biochem. 2016, 109, 525-535. [CrossRef]

59. Zheng, G.; Li, L.; Li, W. Glycerolipidome responses to freezing- and chilling-induced injuries: Examples in arabidopsis and rice. BMC Plant. Biol. 2016, 16, 70. [CrossRef]

60. Hamel, L.P.; Nicole, M.C.; Sritubtim, S.; Morency, M.J.; Ellis, M.; Ehlting, J.; Beaudoin, N.; Barbazuk, B.; Klessig, D.; Lee, J.; et al. Ancient signals: Comparative genomics of plant mapk and mapkk gene families. Trends Plant. Sci. 2006, 11, 192-198. [CrossRef]

61. Kovtun, Y.; Chiu, W.L.; Tena, G.; Sheen, J. Functional analysis of oxidative stress-activated mitogen-activated protein kinase cascade in plants. Proc. Natl. Acad. Sci. USA 2000, 97, 2940-2945. [CrossRef]

62. Teige, M.; Scheikl, E.; Eulgem, T.; Doczi, R.; Ichimura, K.; Shinozaki, K.; Dangl, J.L.; Hirt, H. The mkk2 pathway mediates cold and salt stress signaling in arabidopsis. Mol. Cell 2004, 15, 141-152. [CrossRef]

63. Kim, S.H.; Kim, H.S.; Bahk, S.; An, J.; Yoo, Y.; Kim, J.Y.; Chung, W.S. Phosphorylation of the transcriptional repressor myb15 by mitogen-activated protein kinase 6 is required for freezing tolerance in arabidopsis. Nucleic Acids Res. 2017, 45, 6613-6627. [CrossRef]

64. Zhao, C.; Wang, P.; Si, T.; Hsu, C.C.; Wang, L.; Zayed, O.; Yu, Z.; Zhu, Y.; Dong, J.; Tao, W.A.; et al. Map kinase cascades regulate the cold response by modulating ice1 protein stability. Dev. Cell 2017, 43, 618-629.e5. [CrossRef] [PubMed]

65. Li, H.; Ding, Y.; Shi, Y.; Zhang, X.; Zhang, S.; Gong, Z.; Yang, S. Mpk3- and mpk6-mediated ice1 phosphorylation negatively regulates ice1 stability and freezing tolerance in arabidopsis. Dev. Cell 2017, 43, 630-642.e4. [CrossRef] [PubMed]

66. Xie, G.; Kato, H.; Imai, R. Biochemical identification of the osmkk6-osmpk3 signalling pathway for chilling stress tolerance in rice. Biochem. J. 2012, 443, 95-102. [CrossRef] [PubMed]

67. Zhang, Z.; Li, J.; Li, F.; Liu, H.; Yang, W.; Chong, K.; Xu, Y. Osmapk3 phosphorylates osbhlh002/osice1 and inhibits its ubiquitination to activate ostpp1 and enhances rice chilling tolerance. Dev. Cell 2017, 43, 731-743.e5. [CrossRef] [PubMed]

68. Vogel, J.T.; Zarka, D.G.; Van Buskirk, H.A.; Fowler, S.G.; Thomashow, M.F. Roles of the cbf2 and zat12 transcription factors in configuring the low temperature transcriptome of arabidopsis. Plant. J. 2005, 41, 195-211. [CrossRef] [PubMed]

69. Shi, H.; Ye, T.; Zhong, B.; Liu, X.; Jin, R.; Chan, Z. Athap5a modulates freezing stress resistance in arabidopsis through binding to ccaat motif of atxth21. New Phytol. 2014, 203, 554-567. [CrossRef]

70. van Buer, J.; Cvetkovic, J.; Baier, M. Cold regulation of plastid ascorbate peroxidases serves as a priming hub controlling ros signaling in arabidopsis thaliana. BMC Plant. Biol. 2016, 16, 163. [CrossRef]

71. Park, J.H.; Lee, E.S.; Chae, H.B.; Paeng, S.K.; Wi, S.D.; Bae, S.B.; Thi Phan, K.A.; Lee, S.Y. Disulfide reductase activity of thioredoxin-h2 imparts cold tolerance in arabidopsis. Biochem. Biophys. Res. Commun. 2021, 568, 124-130. [CrossRef]

72. Yun, K.Y.; Park, M.R.; Mohanty, B.; Herath, V.; Xu, F.; Mauleon, R.; Wijaya, E.; Bajic, V.B.; Bruskiewich, R.; de Los Reyes, B.G. Transcriptional regulatory network triggered by oxidative signals configures the early response mechanisms of japonica rice to chilling stress. BMC Plant. Biol. 2010, 10, 16. [CrossRef] [PubMed]

73. Cheng, C.; Yun, K.Y.; Ressom, H.W.; Mohanty, B.; Bajic, V.B.; Jia, Y.; Yun, S.J.; de los Reyes, B.G. An early response regulatory cluster induced by low temperature and hydrogen peroxide in seedlings of chilling-tolerant japonica rice. BMC Genom. 2007, 8, 175. [CrossRef] [PubMed] 
74. Zhang, J.; Luo, W.; Zhao, Y.; Xu, Y.; Song, S.; Chong, K. Comparative metabolomic analysis reveals a reactive oxygen speciesdominated dynamic model underlying chilling environment adaptation and tolerance in rice. New Phytol. 2016, 211, 1295-1310. [CrossRef]

75. Huang, J.; Sun, S.-J.; Xu, D.-Q.; Yang, X.; Bao, Y.-M.; Wang, Z.-F.; Tang, H.-J.; Zhang, H. Increased tolerance of rice to cold, drought and oxidative stresses mediated by the overexpression of a gene that encodes the zinc finger protein zfp245. Biochem. Biophys. Res. Commun. 2009, 389, 556-561. [CrossRef]

76. Sato, Y.; Masuta, Y.; Saito, K.; Murayama, S.; Ozawa, K. Enhanced chilling tolerance at the booting stage in rice by transgenic overexpression of the ascorbate peroxidase gene, osapxa. Plant. Cell Rep. 2011, 30, 399-406. [CrossRef]

77. Wang, X.; Zou, B.; Shao, Q.; Cui, Y.; Lu, S.; Zhang, Y.; Huang, Q.; Huang, J.; Hua, J. Natural variation reveals that ossap16 controls low-temperature germination in rice. J. Exp. Bot. 2018, 69, 413-421. [CrossRef] [PubMed]

78. Cook, D.; Fowler, S.; Fiehn, O.; Thomashow, M.F. A prominent role for the cbf cold response pathway in configuring the low-temperature metabolome of arabidopsis. Proc. Natl. Acad. Sci. USA 2004, 101, 15243-15248. [CrossRef]

79. Dong, C.H.; Agarwal, M.; Zhang, Y.; Xie, Q.; Zhu, J.K. The negative regulator of plant cold responses, hos1, is a ring e3 ligase that mediates the ubiquitination and degradation of ice1. Proc. Natl. Acad. Sci. USA 2006, 103, 8281-8286. [CrossRef]

80. Miura, K.; Jin, J.B.; Lee, J.; Yoo, C.Y.; Stirm, V.; Miura, T.; Ashworth, E.N.; Bressan, R.A.; Yun, D.J.; Hasegawa, P.M. Siz1-mediated sumoylation of ice1 controls cbf3/dreb1a expression and freezing tolerance in arabidopsis. Plant. Cell 2007, 19, 1403-1414. [CrossRef]

81. Agarwal, M.; Hao, Y.; Kapoor, A.; Dong, C.H.; Fujii, H.; Zheng, X.; Zhu, J.K. A r2r3 type myb transcription factor is involved in the cold regulation of cbf genes and in acquired freezing tolerance. J. Biol. Chem. 2006, 281, 37636-37645. [CrossRef]

82. Lee, B.H.; Henderson, D.A.; Zhu, J.K. The arabidopsis cold-responsive transcriptome and its regulation by ice1. Plant. Cell 2005, 17, 3155-3175. [CrossRef]

83. Fursova, O.V.; Pogorelko, G.V.; Tarasov, V.A. Identification of ice2, a gene involved in cold acclimation which determines freezing tolerance in arabidopsis thaliana. Gene 2009, 429, 98-103. [CrossRef]

84. Wathugala, D.L.; Richards, S.A.; Knight, H.; Knight, M.R. Ossfr6 is a functional rice orthologue of sensitive to freezing-6 and can act as a regulator of cor gene expression, osmotic stress and freezing tolerance in arabidopsis. New Phytol. 2011, 191, 984-995. [CrossRef] [PubMed]

85. Ding, Y.; Li, H.; Zhang, X.; Xie, Q.; Gong, Z.; Yang, S. Ost1 kinase modulates freezing tolerance by enhancing ice1 stability in arabidopsis. Dev. Cell 2015, 32, 278-289. [CrossRef]

86. Shi, Y.; Tian, S.; Hou, L.; Huang, X.; Zhang, X.; Guo, H.; Yang, S. Ethylene signaling negatively regulates freezing tolerance by repressing expression of cbf and type-a arr genes in arabidopsis. Plant. Cell 2012, 24, 2578-2595. [CrossRef]

87. Hu, L.; Ye, M.; Li, R.; Zhang, T.; Zhou, G.; Wang, Q.; Lu, J.; Lou, Y. The rice transcription factor wrky53 suppresses herbivoreinduced defenses by acting as a negative feedback modulator of mitogen-activated protein kinase activity. Plant. Physiol. 2015, 169, 2907-2921. [CrossRef]

88. Tian, Y.; Zhang, H.; Pan, X.; Chen, X.; Zhang, Z.; Lu, X.; Huang, R. Overexpression of ethylene response factor terf2 confers cold tolerance in rice seedlings. Transgenic Res. 2011, 20, 857-866. [CrossRef]

89. Chinnusamy, V.; Ohta, M.; Kanrar, S.; Lee, B.H.; Hong, X.; Agarwal, M.; Zhu, J.K. Ice1: A regulator of cold-induced transcriptome and freezing tolerance in arabidopsis. Genes Dev. 2003, 17, 1043-1054. [CrossRef] [PubMed]

90. Ito, Y.; Katsura, K.; Maruyama, K.; Taji, T.; Kobayashi, M.; Seki, M.; Shinozaki, K.; Yamaguchi-Shinozaki, K. Functional analysis of rice dreb1/cbf-type transcription factors involved in cold-responsive gene expression in transgenic rice. Plant. Cell Physiol. 2006, 47, 141-153. [CrossRef]

91. Dubouzet, J.G.; Sakuma, Y.; Ito, Y.; Kasuga, M.; Dubouzet, E.G.; Miura, S.; Seki, M.; Shinozaki, K.; Yamaguchi-Shinozaki, K. Osdreb genes in rice, Oryza sativa l., encode transcription activators that function in drought-, high-salt- and cold-responsive gene expression. Plant. J. 2003, 33, 751-763. [CrossRef]

92. Su, C.F.; Wang, Y.C.; Hsieh, T.H.; Lu, C.A.; Tseng, T.H.; Yu, S.M. A novel mybs3-dependent pathway confers cold tolerance in rice. Plant. Physiol. 2010, 153, 145-158. [CrossRef]

93. Dou, M.; Cheng, S.; Zhao, B.; Xuan, Y.; Shao, M. The indeterminate domain protein roc1 regulates chilling tolerance via activation of dreb1b/cbf1 in rice. Int. J. Mol. Sci. 2016, 17. [CrossRef]

94. Jiang, B.; Shi, Y.; Peng, Y.; Jia, Y.; Yan, Y.; Dong, X.; Li, H.; Dong, J.; Li, J.; Gong, Z.; et al. Cold-induced cbf-pif3 interaction enhances freezing tolerance by stabilizing the phyb thermosensor in arabidopsis. Mol. Plant. 2020, 13, 894-906. [CrossRef]

95. Franklin, K.A.; Whitelam, G.C. Light-quality regulation of freezing tolerance in arabidopsis thaliana. Nat. Genet. 2007, 39, 1410-1413. [CrossRef] [PubMed]

96. Wang, F.; Guo, Z.; Li, H.; Wang, M.; Onac, E.; Zhou, J.; Xia, X.; Shi, K.; Yu, J.; Zhou, Y. Phytochrome a and b function antagonistically to regulate cold tolerance via abscisic acid-dependent jasmonate signaling. Plant. Physiol. 2016, 170, 459-471. [CrossRef]

97. Novák, A.; Boldizsár, Á.; Ádám, É.; Kozma-Bognár, L.; Majláth, I.; Båga, M.; Tóth, B.; Chibbar, R.; Galiba, G. Light-quality and temperature-dependent cbf14 gene expression modulates freezing tolerance in cereals. J. Exp. Bot. 2016, 67, 1285-1295. [CrossRef] [PubMed]

98. Gierczik, K.; Novák, A.; Ahres, M.; Székely, A.; Soltész, A.; Boldizsár, Á.; Gulyás, Z.; Kalapos, B.; Monostori, I.; Kozma-Bognár, L. Circadian and light regulated expression of cbfs and their upstream signalling genes in barley. Int. J. Mol. Sci. 2017, 18, 1828. [CrossRef] [PubMed] 
99. Yang, J.C.; Li, M.; Xie, X.Z.; Han, G.L.; Sui, N.; Wang, B.S. Deficiency of phytochrome b alleviates chilling-induced photoinhibition in rice. Am. J. Bot. 2013, 100, 1860-1870. [CrossRef]

100. He, Y.; Li, Y.; Cui, L.; Xie, L.; Zheng, C.; Zhou, G.; Zhou, J.; Xie, X. Phytochrome b negatively affects cold tolerance by regulating osdreb1 gene expression through phytochrome interacting factor-like protein ospil16 in rice. Front. Plant. Sci. 2016, 7, 1963. [CrossRef]

101. Sanghera, G.S.; Wani, S.H.; Hussain, W.; Singh, N.B. Engineering cold stress tolerance in crop plants. Curr. Genom. 2011, 12, 30-43. [CrossRef]

102. Huang, X.; Zhang, Y.; Zhang, X.; Shi, Y. Long-chain base kinase1 affects freezing tolerance in arabidopsis thaliana. Plant. Sci. 2017, 259, 94-103. [CrossRef]

103. Li, H.; Ye, K.; Shi, Y.; Cheng, J.; Zhang, X.; Yang, S. Bzr1 positively regulates freezing tolerance via cbf-dependent and cbfindependent pathways in arabidopsis. Mol. Plant. 2017, 10, 545-559. [CrossRef] [PubMed]

104. Zwack, P.J.; Compton, M.A.; Adams, C.I.; Rashotte, A.M. Cytokinin response factor 4 (crf4) is induced by cold and involved in freezing tolerance. Plant. Cell Rep. 2016, 35, 573-584. [CrossRef] [PubMed]

105. Kang, N.Y.; Cho, C.; Kim, J. Inducible expression of arabidopsis response regulator 22 (arr22), a type-c arr, in transgenic arabidopsis enhances drought and freezing tolerance. PLoS ONE 2013, 8, e79248. [CrossRef] [PubMed]

106. Ji, H.; Wang, Y.; Cloix, C.; Li, K.; Jenkins, G.I.; Wang, S.; Shang, Z.; Shi, Y.; Yang, S.; Li, X. The arabidopsis rcc1 family protein tcf1 regulates freezing tolerance and cold acclimation through modulating lignin biosynthesis. PLoS Genet. 2015, 11, e1005471. [CrossRef]

107. Liao, P.; Chen, Q.F.; Chye, M.L. Transgenic arabidopsis flowers overexpressing acyl-coa-binding protein acbp6 are freezing tolerant. Plant. Cell Physiol. 2014, 55, 1055-1071. [CrossRef] [PubMed]

108. Nakai, Y.; Fujiwara, S.; Kubo, Y.; Sato, M.H. Overexpression of voz2 confers biotic stress tolerance but decreases abiotic stress resistance in arabidopsis. Plant. Signal. Behav. 2013, 8, e23358. [CrossRef]

109. Seo, P.J.; Park, M.J.; Lim, M.H.; Kim, S.G.; Lee, M.; Baldwin, I.T.; Park, C.M. A self-regulatory circuit of circadian clock-associated1 underlies the circadian clock regulation of temperature responses in arabidopsis. Plant. Cell 2012, 24, 2427-2442. [CrossRef] [PubMed]

110. Lee, H.G.; Seo, P.J. The myb96-hhp module integrates cold and abscisic acid signaling to activate the cbf-cor pathway in arabidopsis. Plant. J. 2015, 82, 962-977. [CrossRef]

111. Kang, H.G.; Kim, J.; Kim, B.; Jeong, H.; Choi, S.H.; Kim, E.K.; Lee, H.Y.; Lim, P.O. Overexpression of ftl1/ddf1, an ap2 transcription factor, enhances tolerance to cold, drought, and heat stresses in arabidopsis thaliana. Plant. Sci. 2011, 180, 634-641. [CrossRef]

112. Chen, J.; Chen, X.; Zhang, Q.; Zhang, Y.; Ou, X.; An, L.; Feng, H.; Zhao, Z. A cold-induced pectin methyl-esterase inhibitor gene contributes negatively to freezing tolerance but positively to salt tolerance in arabidopsis. J. Plant. Physiol. 2018, 222, 67-78. [CrossRef]

113. Chen, Q.F.; Xu, L.; Tan, W.J.; Chen, L.; Qi, H.; Xie, L.J.; Chen, M.X.; Liu, B.Y.; Yu, L.J.; Yao, N.; et al. Disruption of the arabidopsis defense regulator genes sag101, eds1, and pad4 confers enhanced freezing tolerance. Mol. Plant. 2015, 8, 1536-1549. [CrossRef]

114. Fang, J.C.; Tsai, Y.C.; Chou, W.L.; Liu, H.Y.; Chang, C.C.; Wu, S.J.; Lu, C.A. A ccr4-associated factor 1, oscaf1b, confers tolerance of low-temperature stress to rice seedlings. Plant. Mol. Biol. 2021, 105, 177-192. [CrossRef]

115. Fang, C.; Zhang, P.; Li, L.; Yang, L.; Mu, D.; Yan, X.; Li, Z.; Lin, W. Serine hydroxymethyltransferase localised in the endoplasmic reticulum plays a role in scavenging h2o2 to enhance rice chilling tolerance. BMC Plant. Biol. 2020, 20, 236. [CrossRef]

116. Shi, Y.; Phan, H.; Liu, Y.; Cao, S.; Zhang, Z.; Chu, C.; Schlappi, M.R. Glycosyltransferase osugt90a1 helps protect the plasma membrane during chilling stress in rice. J. Exp. Bot. 2020, 71, 2723-2739. [CrossRef]

117. Verma, R.K.; Santosh Kumar, V.V.; Yadav, S.K.; Pushkar, S.; Rao, M.V.; Chinnusamy, V. Overexpression of aba receptor pyl10 gene confers drought and cold tolerance to indica rice. Front. Plant. Sci. 2019, 10, 1488. [CrossRef]

118. Lenka, S.K.; Singh, A.K.; Muthusamy, S.K.; Smita, S.; Chinnusamy, V.; Bansal, K.C. Heterologous expression of rice rna-binding glycine-rich (rbg) gene osrbgd3 in transgenic arabidopsis thaliana confers cold stress tolerance. Funct. Plant. Biol. 2019, 46, 482-491. [CrossRef]

119. Lenka, S.K.; Muthusamy, S.K.; Chinnusamy, V.; Bansal, K.C. Ectopic expression of rice pyl3 enhances cold and drought tolerance in arabidopsis thaliana. Mol. Biotechnol. 2018, 60, 350-361. [CrossRef] [PubMed]

120. Chang, Y.; Nguyen, B.H.; Xie, Y.; Xiao, B.; Tang, N.; Zhu, W.; Mou, T.; Xiong, L. Co-overexpression of the constitutively active form of osbzip46 and aba-activated protein kinase sapk6 improves drought and temperature stress resistance in rice. Front. Plant. Sci. 2017, 8, 1102. [CrossRef] [PubMed]

121. Byun, M.Y.; Cui, L.H.; Oh, T.K.; Jung, Y.J.; Lee, A.; Park, K.Y.; Kang, B.G.; Kim, W.T. Homologous u-box e3 ubiquitin ligases ospub2 and ospub3 are involved in the positive regulation of low temperature stress response in rice (Oryza sativa L.). Front. Plant. Sci. 2017, 8, 16. [CrossRef] [PubMed]

122. Xu, P.; Cai, W. Ran1 is involved in plant cold resistance and development in rice (Oryza sativa). J. Exp. Bot. 2014, 65, 3277-3287. [CrossRef]

123. Chen, N.; Xu, Y.; Wang, X.; Du, C.; Du, J.; Yuan, M.; Xu, Z.; Chong, K. Osran2, essential for mitosis, enhances cold tolerance in rice by promoting export of intranuclear tubulin and maintaining cell division under cold stress. Plant. Cell Env. 2011, 34, 52-64. [CrossRef] 
124. Huang, J.; Sun, S.; Xu, D.; Lan, H.; Sun, H.; Wang, Z.; Bao, Y.; Wang, J.; Tang, H.; Zhang, H. A tfiiia-type zinc finger protein confers multiple abiotic stress tolerances in transgenic rice (Oryza sativa L.). Plant. Mol. Biol. 2012, 80, 337-350. [CrossRef] [PubMed]

125. Jin, Y.M.; Piao, R.; Yan, Y.F.; Chen, M.; Wang, L.; He, H.; Liu, X.; Gao, X.A.; Jiang, W.; Lin, X.F. Overexpression of a new zinc finger protein transcription factor osctzfp8 improves cold tolerance in rice. Int J. Genom. 2018, 2018, 5480617. [CrossRef]

126. Huang, L.; Hong, Y.; Zhang, H.; Li, D.; Song, F. Rice nac transcription factor onac095 plays opposite roles in drought and cold stress tolerance. BMC Plant. Biol. 2016, 16, 203. [CrossRef] [PubMed]

127. Song, S.Y.; Chen, Y.; Chen, J.; Dai, X.Y.; Zhang, W.H. Physiological mechanisms underlying osnac5-dependent tolerance of rice plants to abiotic stress. Planta 2011, 234, 331-345. [CrossRef] [PubMed]

128. Yokotani, N.; Sato, Y.; Tanabe, S.; Chujo, T.; Shimizu, T.; Okada, K.; Yamane, H.; Shimono, M.; Sugano, S.; Takatsuji, H.; et al. Wrky76 is a rice transcriptional repressor playing opposite roles in blast disease resistance and cold stress tolerance. J. Exp. Bot. 2013, 64, 5085-5097. [CrossRef]

129. Wang, C.; Wei, Q.; Zhang, K.; Wang, L.; Liu, F.; Zhao, L.; Tan, Y.; Di, C.; Yan, H.; Yu, J.; et al. Down-regulation of osspx1 causes high sensitivity to cold and oxidative stresses in rice seedlings. PLoS ONE 2013, 8, e81849. [CrossRef]

130. Yang, A.; Dai, X.; Zhang, W.H. A r2r3-type myb gene, osmyb2, is involved in salt, cold, and dehydration tolerance in rice. J. Exp. Bot. 2012, 63, 2541-2556. [CrossRef]

131. Lv, Y.; Yang, M.; Hu, D.; Yang, Z.; Ma, S.; Li, X.; Xiong, L. The osmyb30 transcription factor suppresses cold tolerance by interacting with a jaz protein and suppressing beta-amylase expression. Plant. Physiol. 2017, 173, 1475-1491. [CrossRef] [PubMed]

132. Liu, C.; Wu, Y.; Wang, X. Bzip transcription factor osbzip52/risbz5: A potential negative regulator of cold and drought stress response in rice. Planta 2012, 235, 1157-1169. [CrossRef]

133. Tao, Z.; Kou, Y.; Liu, H.; Li, X.; Xiao, J.; Wang, S. Oswrky45 alleles play different roles in abscisic acid signalling and salt stress tolerance but similar roles in drought and cold tolerance in rice. J. Exp. Bot. 2011, 62, 4863-4874. [CrossRef] [PubMed]

134. Chen, X.; Wang, Y.; Lv, B.; Li, J.; Luo, L.; Lu, S.; Zhang, X.; Ma, H.; Ming, F. The nac family transcription factor osnap confers abiotic stress response through the aba pathway. Plant. Cell Physiol. 2014, 55, 604-619. [CrossRef]

135. Liu, H.; Ma, Y.; Chen, N.; Guo, S.; Liu, H.; Guo, X.; Chong, K.; Xu, Y. Overexpression of stress-inducible osburp16, the beta subunit of polygalacturonase 1 , decreases pectin content and cell adhesion and increases abiotic stress sensitivity in rice. Plant. Cell Env. 2014, 37, 1144-1158. [CrossRef]

136. Li, C.R.; Liang, D.D.; Xu, R.F.; Li, H.; Zhang, Y.P.; Qin, R.Y.; Li, L.; Wei, P.C.; Yang, J.B. Overexpression of an alternative oxidase gene, osaox1a, improves cold tolerance in Oryza sativa L. Genet. Mol. Res. 2013, 12, 5424-5432. [CrossRef]

137. Zhang, Z.; Zhang, Q.; Wu, J.; Zheng, X.; Zheng, S.; Sun, X.; Qiu, Q.; Lu, T. Gene knockout study reveals that cytosolic ascorbate peroxidase 2 (osapx2) plays a critical role in growth and reproduction in rice under drought, salt and cold stresses. PLoS ONE 2013, 8, e57472. [CrossRef]

138. Zhang, J.; Li, J.; Wang, X.; Chen, J. Ovp1, a vacuolar h+-translocating inorganic pyrophosphatase (v-ppase), overexpression improved rice cold tolerance. Plant. Physiol Biochem. 2011, 49, 33-38. [CrossRef]

139. Li, H.W.; Zang, B.S.; Deng, X.W.; Wang, X.P. Overexpression of the trehalose-6-phosphate synthase gene ostps1 enhances abiotic stress tolerance in rice. Planta 2011, 234, 1007-1018. [CrossRef]

140. Park, M.R.; Yun, K.Y.; Mohanty, B.; Herath, V.; Xu, F.; Wijaya, E.; Bajic, V.B.; Yun, S.J.; De Los Reyes, B.G. Supra-optimal expression of the cold-regulated osmyb4 transcription factor in transgenic rice changes the complexity of transcriptional network with major effects on stress tolerance and panicle development. Plant. Cell Env. 2010, 33, 2209-2230. [CrossRef] 